\title{
FosB Regulates Stretch-Induced Expression of Extracellular Matrix Proteins in Smooth Muscle
}

\author{
Aruna Ramachandran, Edward M. Gong, \\ Kristine Pelton, Sandeep A. Ranpura, \\ Michelle Mulone, Abhishek Seth, Pablo Gomez III, \\ and Rosalyn M. Adam \\ From the Urological Diseases Research Center, Children's Hospital \\ Boston, and the Department of Surgery, Harvard Medical School, \\ Boston, Massachusetts
}

Fibroproliferative remodeling in smooth muscle-rich hollow organs is associated with aberrant extracellular matrix (ECM) production. Although mechanical stimuli regulate ECM protein expression, the transcriptional mediators of this process remain poorly defined. Previously, we implicated AP-1 as a mediator of smooth muscle cell (SMC) mechanotransduction; however, its role in stretch-induced ECM regulation has not been explored. Herein, we identify a novel role for the AP-1 subunit FosB in stretch-induced ECM expression in SMCs. The DNA-binding activity of AP-1 increased after stretch stimulation of SMCs in vitro. In contrast to c-Jun and c-fos, which are also activated by the SMC mitogen platelet-derived growth factor, FosB was only activated by stretch. FosB silencing attenuated the expression of the profibrotic factors tenascin C (TNC) and connective tissue growth factor (CTGF), whereas forced expression of Jun $\sim$ FosB stimulated TNC and CTGF promoter activity. Chromatin immunoprecipitation revealed enrichment of AP-1 at the TNC and CTGF promoters. Bladder distension in vivo enhanced nuclear localization of c-jun and FosB. Finally, the distension-induced expression of TNC and CTGF in the detrusor smooth muscle of bladders from wild-type mice was significantly attenuated in FosBnull mice. Together, these findings identify FosB as a mechanosensitive regulator of ECM production in smooth muscle. (Am J Pathol 2011, 179:2977-2989; DOI: 10.1016/j.ajpath.2011.08.034)

Mechanical stimulation is a critical regulator of the normal development of hollow organs, including the heart, vasculature, airways, and urinary bladder. ${ }^{1}$ However, exposure of tissues to sustained and/or excessive distension, resulting from increased hemodynamic forces or obstruction, often leads to pathological tissue remodeling. These changes are characterized by cellular hypertrophy and hyperplasia, altered production, and turnover of extracellular matrix (ECM) and inflammation. Although adaptive in the beginning, they will eventually compromise organ function. Among the pathological changes that occur in response to tissue damage, the fibrosis that results from aberrant ECM deposition and loss of tissue flexibility are major contributors to organ dysfunction. ${ }^{2}$ However, although the macroscopic alterations that characterize fibrosis in hollow organs exposed to such pathological distension have been appreciated for many years, the signaling networks that mediate tissue remodeling at the molecular level are still poorly understood.

Previous data from our laboratory identified several factors that mediate mechanotransduction in primary smooth muscle cells (SMCs). ${ }^{3-6}$ Unbiased in silico analysis of microarray data from human bladder SMCs exposed to defined mechanical stimulation revealed an overrepresentation of genes harboring binding sites for AP- $1,{ }^{6}$ consistent with previous observations ${ }^{3,4,7,8}$ showing that mechanical stimulation of SMCs up-regulates AP-1 DNA-binding activity. However, a role for AP-1 in the regulation of stretch-induced gene expression in vivo is only beginning to be explored. Furthermore, although there is some evidence for redundancy among AP-1 components, targeted mutation of individual AP-1 subunits in vivo suggests nonoverlapping functions ${ }^{9}$ consistent with discrete roles for individual AP-1 dimers.

Although several reports have provided correlative evidence linking induction of AP-1 subunits with expression of factors comprising either components of the $\mathrm{ECM}^{10,11}$ or regulators of ECM turnover in different mechanosensi-

Supported by the AUA Foundation Research Scholar Program (A.R.), the Children's Hospital Boston Office of Fellowship Training Career Development Fellowship Award (A.R.), grants from the NIH (R01 DK077195, R01 DK077195-02S1, and R21 DK66412 to R.M.A.), and the Edwin Beer Fellowship from the New York Academy of Medicine (R.M.A.).

Accepted for publication August 9, 2011

Address reprint requests to Rosalyn M. Adam, Ph.D., Urological Diseases Research Center, Enders Research Laboratories, Room 1061.1, Children's Hospital Boston, 300 Longwood Ave, Boston, MA 02115. E-mail: rosalyn.adam@childrens.harvard.edu. 
tive cell types, ${ }^{12-14}$ the role of specific AP-1 species in driving these processes in SMCs has not been explored. Based on prior evidence identifying AP-1 as a stretchsensitive transcription factor in $\mathrm{SMCs}^{3,4,7,8,15}$ and the known impact of inappropriate mechanical stimulation on ECM production and turnover in hollow organs, such as the bladder, ${ }^{16,17}$ we hypothesized that AP-1 was a candidate regulator of this process.

In this study, we present evidence that the AP-1 subunit FosB is selectively activated by mechanical stimulation of SMCs. Moreover, we demonstrate, for the first time to our knowledge, that FosB is an essential regulator of ECM protein expression in response to bladder distension. In particular, we show that the profibrotic genes tenascin C (TNC) and connective tissue growth factor (CTGF) are robustly activated in SMCs upon stretch, both in vitro and in two complementary rodent models of bladder outlet obstruction, and that genetic ablation of FosB attenuates distension-induced TNC and CTGF expression. Collectively, these findings imply that FosB represents a potential node for therapeutic intervention to mitigate the deleterious effects of pathological tissue remodeling in hollow organs.

\section{Materials and Methods}

\section{In Vitro Monolayer Cyclic Stretch-Relaxation}

Primary human bladder SMCs (pBSMCs) were seeded at 8 to $10 \times 10^{4}$ cells/well in six-well silicone elastomerbottomed culture plates coated with type I collagen (Bioflex; Flexcell, Hillsborough, NC) and grown to approximately $80 \%$ confluence in Dulbecco's modified Eagle's medium (DMEM) supplemented with 10\% fetal bovine serum (both from GIBCO/Life Technologies, Gaithersburg, MD), penicillin (100 U/mL), and streptomycin (100 $\mu \mathrm{g} / \mathrm{mL}$ ) at $37^{\circ} \mathrm{C}$ in a humidified atmosphere of $95 \%$ air and $5 \% \mathrm{CO}_{2}$. All experiments were performed on cells between passages 3 and 5 . Cells were subjected to serum depletion (DMEM/0.5\% fetal bovine serum) for 48 hours. Cells were subjected to continuous cycles of stretch-relaxation for the indicated times, using a computer-driven, vacuum-operated, stretch-inducing device (Strain Unit FX-4000; Flexcell, Hillsborough, NC), as previously described. ${ }^{3,5}$ Each cycle consisted of 5 seconds of stretch and 5 seconds of relaxation $(0.1 \mathrm{~Hz})$ under conditions of $20 \%$ maximum radial stretch at the periphery of the membrane. Cells incubated in parallel under identical conditions, but without exposure to stretch, served as the control.

\section{Preparation of Nuclear Extracts}

Nuclear extracts from stretched and nonstretched pBSMCs were prepared essentially, as previously described. ${ }^{18}$ Briefly, cells were scraped in PBS, allowed to swell for 15 minutes at $4^{\circ} \mathrm{C}$ in hypotonic buffer $\mathrm{A}$ (10 $\mathrm{mmol} / \mathrm{L} \mathrm{HEPES} ; 10 \mathrm{mmol} / \mathrm{L} \mathrm{KCl} ; 0.1 \mathrm{mmol} / \mathrm{L}$ EDTA, $\mathrm{pH}$ 8.0; $0.1 \mathrm{mmol} / \mathrm{L}$ EGTA; $2 \mu \mathrm{g} / \mathrm{mL}$ leupeptin; $1 \mathrm{mmol} / \mathrm{L}$ dithiothreitol; and protease inhibitors; Complete Mini; Roche Applied Science, Indianapolis, IN), and vortex mixed to release nuclei. Nuclei were recovered by centrifugation at $1000 \times g$ for 10 minutes, and pellets were resuspended in buffer $B(20$ mmol/L HEPES, pH 7.9; 0.42 $\mathrm{mol} / \mathrm{L} \mathrm{NaCl} ; 1 \mathrm{mmol} / \mathrm{L}$ EDTA; $1 \mathrm{mmol} / \mathrm{L}$ EGTA; $2 \mu \mathrm{g} / \mathrm{mL}$ leupeptin; and $1 \mathrm{mmol} / \mathrm{L}$ dithiothreitol and protease inhibitors) for 1 hour at $4^{\circ} \mathrm{C}$. The suspension was centrifuged at $12,000 \times g$ for 15 minutes, and supernatant was used as nuclear extract. Protein was quantified by the BioRad DC protein assay (BioRad Laboratories, Hercules, CA).

\section{EMSA Data}

Electrophoretic mobility shift analyses (EMSAs) for AP-1 were performed with 3 to $5 \mu \mathrm{g}$ of nuclear extract and 0.5 ng of ${ }^{32} \mathrm{P}$-labeled oligonucleotide probe in a $20-\mu \mathrm{L}$ reaction volume containing $25 \mathrm{mmol} / \mathrm{L}$ Tris- $\mathrm{HCl}, \mathrm{pH} 8 ; 50$ $\mathrm{mmol} / \mathrm{L} \mathrm{KCl} ; 5 \mathrm{mmol} / \mathrm{L} \mathrm{MgCl}_{2} ; 0.5 \mathrm{mmol} / \mathrm{L}$ EDTA; $8 \%$ glycerol; $2 \mu \mathrm{g}$ of BSA; and $0.5 \mu \mathrm{g}$ of poly(dl-dC). The reaction was incubated for 20 minutes at room temperature, and the DNA-protein complexes were resolved on $5 \%$ polyacrylamide gels in $0.5 \times$ Tris-borate-EDTA buffer at $4^{\circ} \mathrm{C}$. The gels were dried, and the complexes were visualized by autoradiography using a Typhoon Trio Variable Mode phosphorimager (GE Healthcare Biosciences, Piscataway, NJ). For competition experiments, a 50-fold molar excess of the cold competitor oligonucleotide was added simultaneously with the probe. For supershift experiments, phospho-C-Jun antibody (KM-1, sc-822X; Santa Cruz Biotechnology, Santa Cruz, CA) was preincubated on ice for 1 hour with nuclear extract, followed by the addition of the other components for 20 minutes at room temperature. The following oligonucleotides were used in EMSAs: AP-1 wt, containing the consensus AP1-binding site (5'-CGCTTGATGACTCAGCCGGAA-3'); and AP-1 mut-containing mutations (underlined) in the consensus AP-1 site (5'-CGCTTGATGACTTGGCCGGAA-3').

\section{Transcription Factor ELISA}

To examine activation of multiple AP-1 subunits concurrently, we used a commercially available AP-1 family transcription factor enzyme-linked immunosorbent assay (ELISA; Active Motif, Carlsbad, CA). Nuclear extracts, 3 to $5 \mu \mathrm{g}$, isolated from stretched and nonstretched cells, as previously described, were assayed according to the manufacturer's protocol. In selected experiments, cells were preincubated with kinase inhibitors (LY294002, SP600125, and SB202190, all at $10 \mu \mathrm{mol} / \mathrm{L}$ ) or dimethyl sulfoxide vehicle for 1 hour before the initiation of stretch for a further 2 hours.

\section{Co-Immunoprecipitation and Immunoblot Analysis}

After exposure to stretch, pBSMCs were washed twice with PBS and lysed in lysis buffer (50 mmol/L HEPES, $\mathrm{pH}$ $8.0 ; 1 \mathrm{mmol} / \mathrm{L}$ EDTA; $0.5 \mathrm{mmol} / \mathrm{L}$ EGTA; $140 \mathrm{mmol} / \mathrm{L} \mathrm{NaCl}$ $10 \%$ glycerol; $0.5 \%$ Nonidet P-40; $100 \mathrm{ng} / \mathrm{mL}$ aprotinin; $100 \mathrm{ng} / \mathrm{mL}$ pepstatin $\mathrm{A}$; and $2 \mu \mathrm{g} / \mathrm{mL}$ leupeptin) for 10 
minutes on ice. Cell suspensions were vortex mixed three times for 5 seconds and centrifuged at 10,000 $\times g$ for 15 minutes at $4^{\circ} \mathrm{C}$. Supernatants were transferred to fresh tubes, and protein was quantified by the Bradford assay. Co-immunoprecipitation was performed with $1 \mathrm{mg}$ of protein extract in $750 \mu \mathrm{L}$ of lysis buffer. Samples were precleared with $20 \mu \mathrm{L}$ of Protein A/G beads (Santa Cruz Biotechnology) for 1 hour at $4^{\circ} \mathrm{C}$ and centrifuged at 1000 $\times g$ for 1 minute. Supernatants were incubated overnight at $4^{\circ} \mathrm{C}$ with either $5 \mu \mathrm{g}$ of c-Fos or FosB antibody (Cell Signaling Technology, Danvers, MA) or $5 \mu \mathrm{g}$ of isotype IgG control. Antibody-antigen complexes were precipitated at $4^{\circ} \mathrm{C}$ for 1 hour with $40 \mu \mathrm{L}$ of Protein $\mathrm{A} / \mathrm{G}$ beads (Santa Cruz Biotechnology), and complexes were washed three times with $1 \mathrm{~mL}$ of lysis buffer before elution in $40 \mu \mathrm{L}$ of Laemmli buffer at $100^{\circ} \mathrm{C}$ for 10 minutes. Cell extracts (20 $\mu \mathrm{g} / \mathrm{lane})$ or immunoprecipitation eluates were resolved by $10 \%$ SDS-PAGE and electrotransferred to nitrocellulose membranes. After transfer, membranes were stained with Ponceau $S$ to confirm equal loading, where appropriate. Membranes were blocked with PBS/ $0.1 \%$ Tween-20/10\% nonfat dried milk for 1 hour at room temperature. Anti-C-Jun (Cell Signaling Technology, 1:1000) or anti-glyceraldehyde-3-phosphate dehydrogenase (Santa Cruz Biotechnology, 1:8000) antibodies prepared in 5\% nonfat dried milk or anti-c-Fos or FosB (1: $1000)$ antibody prepared in PBS-T (0.1\% Tween-20) was added to membranes and incubated overnight at $4^{\circ} \mathrm{C}$. Membranes were washed three times for 15 minutes with PBS-T, followed by the addition of species-specific horseradish peroxidase-conjugated secondary antibodies in 10\% milk/PBS-T for 1 hour at room temperature. Membranes were washed three times for 15 minutes with PBS-T before detection of signals using SuperSignal chemiluminescence reagent (Pierce Chemical Co, Rockford, IL) and exposure of blots to X-ray film.

\section{Rodent Bladder Distension Models}

An ex vivo model of bladder stretch injury was used, as previously described. ${ }^{6,19}$ Briefly, 6- to 8-week-old female rats were anesthetized with isoflurane inhalation. The bladder was catheterized and distended to $40 \mathrm{~cm} \mathrm{H}_{2} \mathrm{O}$ pressure using a gravity manometer with serum-free DMEM. A low midline incision was made to expose the bladder. The bladder neck was isolated and tightened with a 4-0 silk suture. The catheter was removed, and the bladder was excised. The excised bladder was placed in serum-free DMEM and maintained in culture at $37^{\circ} \mathrm{C}$ in a humidified $5 \% \mathrm{CO}_{2}$ and $95 \%$ air atmosphere incubator. As a control, a nondistended bladder was harvested and incubated in parallel with the stretch bladder as a control. Two bladders were used for each time point (stretch and nonstretch).

To determine the impact of bladder distension in an intact animal, we also used an acute bladder outlet obstruction model, essentially as described. ${ }^{20}$ Briefly, 6-week-old female CD-1 mice under isoflurane anesthesia were subjected to laparotomy to expose the bladder. The proximal urethra was ligated with a $6-0$ nylon suture, and the mice were recovered after closure of the abdom- inal wall. Bladder distension was achieved by urine production by the animal over a 24-hour period, after which organs were harvested. In selected experiments, we used FosB ${ }^{-1-}$ mice obtained from Jackson Laboratories (stock no. 003077; Bar Harbor, ME). The mice harbor a genomic deletion of FosB exon 2 that results in loss of FosB function. ${ }^{21}$ Harvested tissues were either fixed in $10 \%$ neutral-buffered formalin and embedded in paraffin, embedded in optimal cutting temperature compound (Tissue-Tek, Sakura Finetek, Torrance, CA) at $-80^{\circ} \mathrm{C}$, or snap frozen for isolation of protein. All procedures were approved by the Children's Hospital Institutional Animal Care and Use Committee.

\section{Laser-Capture Microdissection and RT-PCR}

Tissues embedded in optimal cutting temperature compound were divided (10 $\mu \mathrm{m}$ sections) using a Leica Cryostat (Leica Microsystems, Buffalo Grove, IL) and mounted on polyethylenenaphthalate membrane slides. After brief (10-second) exposure of tissues to hematoxylin to visualize tissue compartments, sections were microdissected to isolate smooth muscle from urothelium. RNA was isolated using the PicoPure RNA Isolation reagent (Arcturus, Mountain View, CA), reverse transcribed using the High Capacity cDNA Synthesis kit (Applied Biosystems, Foster City, CA), and amplified with gene-specific primers, as previously described. ${ }^{18}$

\section{Immunostaining of Bladder Tissue Sections}

Sections (8 $\mu \mathrm{m}$ thick) of FFPE bladder tissue on glass slides were deparaffinized in xylene, rehydrated through alcohol grades, and equilibrated in PBS for 10 minutes. For staining of AP-1 subunits, antigen retrieval of tissue sections was performed with $10 \mathrm{mmol} / \mathrm{L}$ citrate buffer, $\mathrm{pH}$ 6.0 , at $100^{\circ} \mathrm{C}$ for 10 minutes. Sections were allowed to $\mathrm{cool}$ at room temperature for 20 minutes and blocked with $5 \%$ normal goat serum, prepared in PBS $/ 0.1 \%$ Triton X-100 for 1 hour at room temperature. Antibodies (all from Cell Signaling Technology) were prepared in 5\% normal goat serum (c-Jun, 1:50; FosB, 1:25) and added to sections for overnight incubation at $4^{\circ} \mathrm{C}$ in a moist chamber. Slides were washed three times with PBS for 10 minutes before the addition of Cy3-conjugated secondary antirabbit antibody (1:250) for 2 hours at room temperature. Slides were washed three times with PBS for 10 minutes and mounted with Vectamount-containing DAPI before visualization of sections using a Zeiss Axioplan-2 fluorescence microscope (Carl Zeiss Microlmaging, Inc., Thornwood, NY). The extent of nuclear localization of c-Jun and FosB was quantified by two independent observers (S.A.R. and M.M.) by determination of nuclear signal for each antigen relative to total cell number in each of three high-power fields.

\section{Knockdown of FosB by siRNA}

To target the expression of FosB in pBSMCs, approximately $2.4 \times 10^{6}$ cells were nucleofected with $100 \mathrm{pmol}$ of either nontargeting (control) or FosB-specific small- 
interfering RNA (siRNA) oligonucleotides using program A-033 on a Nucleofector IIN (Amaxa, Inc., Gaithersburg). Approximately $1.8 \times 10^{5}$ cells from each nucleofection reaction were seeded in either plastic or Bioflex plates for cyclic stretch-relaxation, as previously described. Cells were harvested for evaluation of knockdown efficiency by immunoblot analysis or for isolation of RNA after stretch for determination of gene expression. In selected experiments, cell proliferation was monitored by the addition of MTS [3-(4,5-dimethylthiazol-2-yl)-5-(3-carboxymethoxyphenyl)-2-(4-sulfophenyl)-2H-tetrazolium] reagent (CellTiter 96 AQueous solution; Promega Corp., Madison, WI) for 4 hours, after which the absorbance of the culture medium was determined at $490 \mathrm{~nm}$.

\section{ChIP Analysis}

Chromatin was prepared from pBSMCs subjected to cyclic stretch-relaxation for 24 hours and immunoprecipitated using antibodies to c-Jun or FosB, essentially as previously described, ${ }^{18}$ using the ChIP-It Express kit (Active Motif, Carlsbad, CA). After reversal of cross-links, eluted DNA was amplified using primers flanking AP-1 motifs located at $-650 /-644$ in the CTGF promoter and an AP-1 motif at $-876 /-870$ within the TNC promoter. Controls included reactions from chromatin immunoprecipitated with control IgG. DNA amplification was performed by semiquantitative real-time PCR analysis, and results are presented as fold change for each sample over its respective IgG control, subsequent to normalization with input DNA. The primer sequences used for PCR are given as follows: TNC chromatin immunoprecipitation (ChIP), 5'-GGTGAAGTGCTACTTCTCCACTCCCTT-3' (forward) and 5'-AATCCTTGAGCCATAAGCTGCGCCTTT-3' (reverse); and CTGF ChIP, 5'-ATGGCCACTCCTCCCTTGTCC-3' (forward) and 5'-CATTTGTCACTTGAGGTAACGG-3' (reverse).

\section{Luciferase Assays}

Genomic DNA fragments comprising approximately $1 \mathrm{~kb}$ of the human TNC and CTGF promoters were amplified and subcloned into pGL4 using standard approaches. pBSMC or HEK293 cells were plated at a density of 100,000 to 300,000 cells per well of a six-well plate and were transiently cotransfected the next day with $250 \mathrm{ng}$ of TNC or CTGF luciferase constructs, along with $500 \mathrm{ng}$ of a tethered C-Jun FosB dimer or vector alone (EF1 $\alpha)$ using Trans/T-LT1 reagent (Mirus Bio LLC, Madison). At 24 hours after transfection, cells were harvested in reporter lysis buffer and luciferase activity was determined using a Luciferase Assay System kit, according to the manufacturer's instructions (Promega Corp), as described. ${ }^{18}$ Luciferase values were normalized to total protein, as determined using the MicroBCA assay reagent (Thermo Scientific, Waltham, MA).

\section{Results}

\section{Cyclic Stretch Relaxation Induces AP-1 in Primary Human BSMCs}

Previous microarray analysis from our laboratory demonstrated mechanical stretch as a highly selective regulator of gene expression in human bladder SMCs, with expression of only 20 genes of 11,731 altered more than twofold after stretch. In silico analysis of differentially expressed genes using the FIRED algorithm revealed an overrepresentation of AP-1-binding sites in the promoters of stretch-responsive genes. ${ }^{6}$ To extend this bioinformatics observation, we investigated AP-1 complex formation in pBSMCs in response to mechanical stretch using EMSAs. Nuclear extracts of control (nonstretched) pBSMCs or cells exposed to cyclic stretch-relaxation for 2 hours were incubated with a labeled oligonucleotide incorporating a consensus AP-1-binding site. As shown in Figure 1A, we observed complex formation in pBSMCs that was increased in response to stretch. The complex was competed out, with corresponding unlabeled probe incorporating the AP-1 site (compare lanes 3 to 5 with lanes 10 to 12) but not with a mutant version of the probe in which the AP-1-binding motif was mutated (compare lanes 6 to 8 with lanes 13 to 15). To confirm the identity of the nuclear proteins in the complex as AP-1 family members, we performed supershift analysis using antibody to phosphorylated (activated) C-Jun. As shown in Figure 1B, we observed supershift of the complex in the presence of p-c-Jun antibody (which recognizes phosphorylated cJun) but not with the IgG control. However, further identification of additional AP-1 family members in the DNAprotein complex was limited by the availability of antibodies suitable for supershift analysis.

\section{FosB Is Selectively Induced by Stretch}

To gain further insight into the AP-1 subunits present in the DNA complex after stretch stimulation, we used a transcription factor ELISA. This approach allowed comprehensive and quantitative determination of AP-1-binding activity under defined conditions. Consistent with the EMSA, stretch-induced DNA-binding activity of phosphoc-Jun (Figure 1C) by 1.8-fold. We also observed activation of c-Fos and FosB, by 2.7- and 1.95-fold, respectively, whereas little or no activation of JunB, JunD, Fra1, or Fra2 was evident under the conditions used herein. This pattern differed from that obtained in pBSMCs exposed to another SMC mitogen, platelet-derived growth factor, as previously described. ${ }^{18}$ In that study, we observed activation of phospho-C-Jun, C-Fos, Fra1, and Fra2, but not FosB, consistent with previous findings ${ }^{22}$ showing that FosB was insensitive to platelet-derived growth factor. These observations indicate that, among the Fos family members, FosB is selectively activated by mechanical signals in pBSMCs, whereas C-Jun appears to be the relevant Jun family protein induced by stretch; therefore, the c-Jun-FosB species became the focus of the study. We also demonstrated an increase in protein levels of C-Jun, Fos, and FosB with stretch (Figure 1D), as 
A

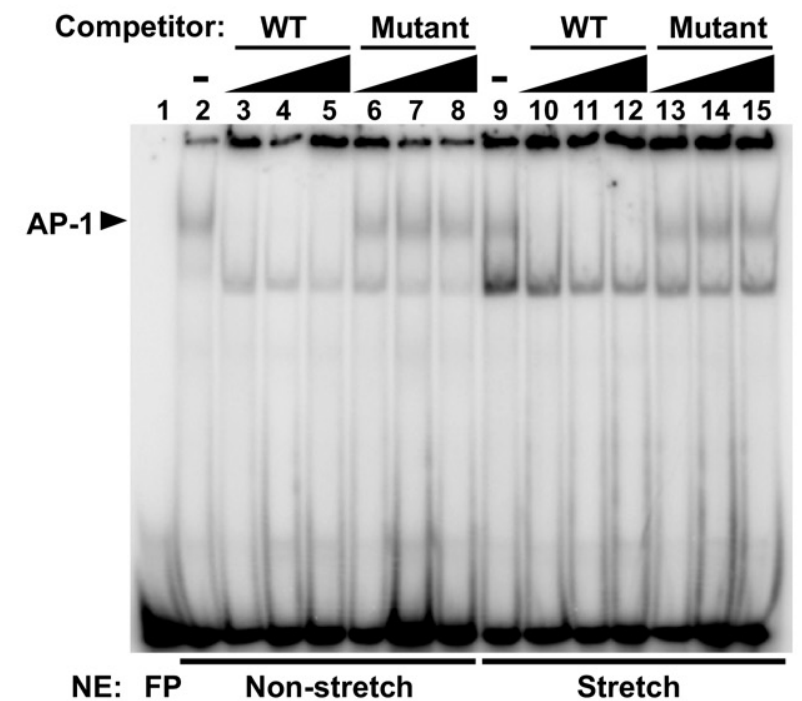

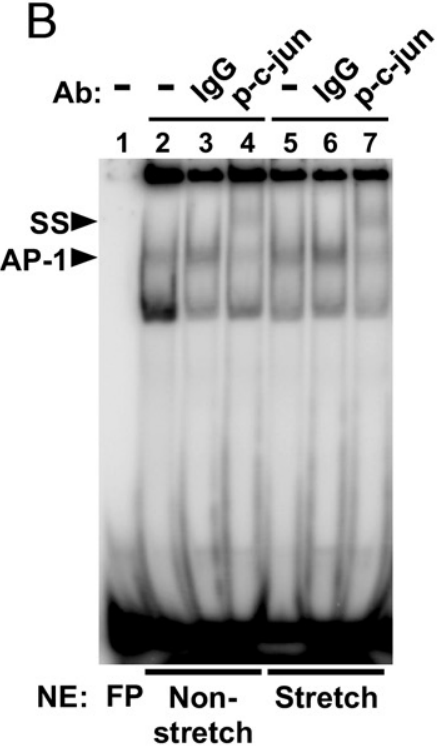
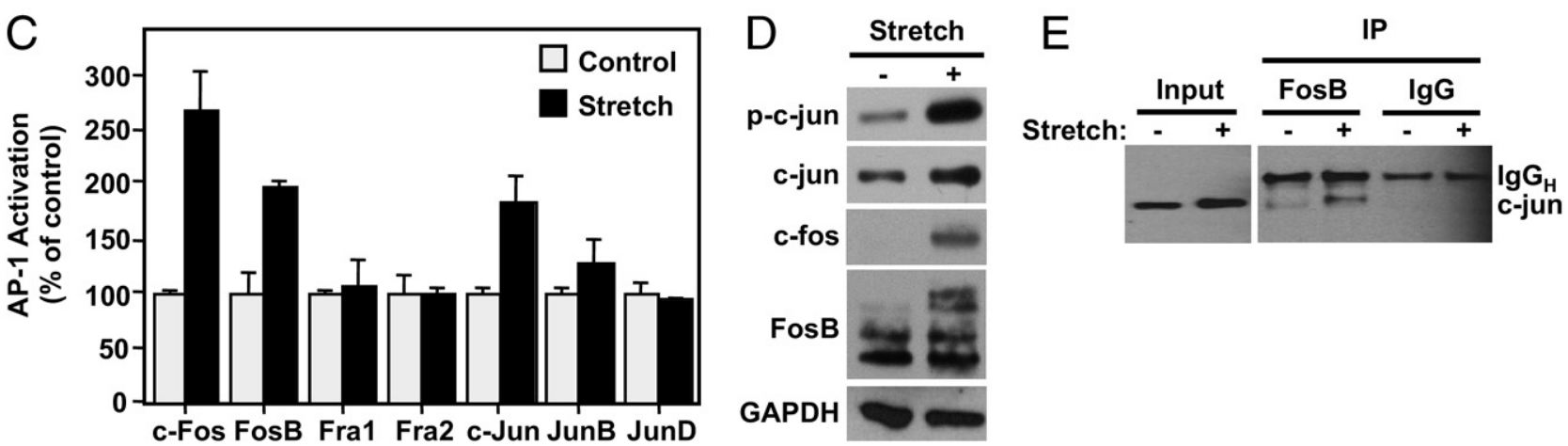

Figure 1. Stretch stimulation activates select members of the AP-1 family of transcription factors. A: Nuclear extracts (NE) prepared from control or stretchstimulated pBSMCs were used in an EMSA and assessed for binding to a radiolabeled oligonucleotide carrying a consensus AP-1-binding sequence motif AP-1-DNA complex formation was detected in both basal and stretch-stimulated pBSMCs (lanes 2 and 9), which was competed out by increasing amounts of unlabeled homologous competitor oligonucleotide [wild type (WT), lanes 3 to 5 and 10 to 12] but not by competitor oligonucleotides carrying a mutated AP-1 site (mutant, lanes 6 to 8 and 13 to 15). Lane 1 is the free radiolabeled probe (no nuclear extract added) FP, free probe. B: The AP-1 complex (lanes 2 and 5 ) was supershifted (SS) in the presence of antibody to phospho-c-Jun (lanes 4 and 7) but not by an isotype-matched IgG control (lanes 3 and 6). Lane 1, free probe. C: Nuclear extracts from pBSMCs subjected to cyclic stretch for 2 hours or not (control) were assayed using a transcription factor ELISA to determine the DNA-binding activity of AP-1 proteins. The graph shows AP-1 binding expressed as a percentage of control for each of seven AP-1 subunits, and data are representative of at least two independent experiments. Increased binding of c-Jun, Fos, and FosB proteins to a consensus AP-1 oligonucleotide was observed in stretch-treated cells relative to controls. D: Protein lysates from pBSMCs (control or stretched for 24 hours) were immunoblotted with the indicated antibodies. E: Lysates from stretched (24 hours) or control pBSMCs were immunoprecipitated with FosB or isotype-matched IgG control antibodies and immunoblotted for c-Jun. An increase in Jun-FosB interaction is observed on stretch. The decrease in mobility of the c-Jun band is likely because of protein phosphorylation, consistent with $\mathbf{D}$. Nonspecific interaction with the heavy chain of IgG in the sepharose beads used for immunoprecipitation (IP) is observed (IgG $\mathrm{H}_{\mathrm{H}}$. All data shown are representative of at least three independent experiments.

well as an increase in phosphorylated (active) c-Jun. Finally, we verified stretch-induced formation of a c-Jun$\sim$ FosB dimer in pBSMCs by co-immunoprecipitation-immunoblot analysis. As shown in Figure 1E, c-Jun and FosB showed increased association in response to stretched compared with nonstretched cells.

\section{Stretch-Induced Expression of Genes Encoding ECM Proteins Is FosB Dependent}

In light of previously published reports ${ }^{5}$ from our laboratory and others that stretch induces pBSMC growth, we investigated the potential role of AP-1, specifically FosB, in this process. We evaluated pBSMC growth, using an MTS assay, with cells subjected to stretch or control (nonstretch) conditions for 24 and 48 hours, subsequent to transfection with control or FosB siRNAs. We observed that FosB knockdown suppressed basal growth but had no appreciable effect on stretch-induced growth (data not shown). In addition to the effect of stretch on cell growth, chronic stretch of hollow organs in vivo is a wellknown trigger of aberrant ECM protein production and turnover, leading to fibrosis. ${ }^{2}$ To determine whether altered ECM production was a short-term response to mechanical stimulation of pBSMCs, we profiled the expression of 84 genes encoding ECM and adhesion molecules in pBSMCs exposed to stretch for 24 hours. This analysis revealed 13 genes that were induced and 5 genes that were downregulated twofold or greater by mechanical stimulation (Figure $2 \mathrm{~A}$ ). To determine which of the mechanosensitive genes 
A

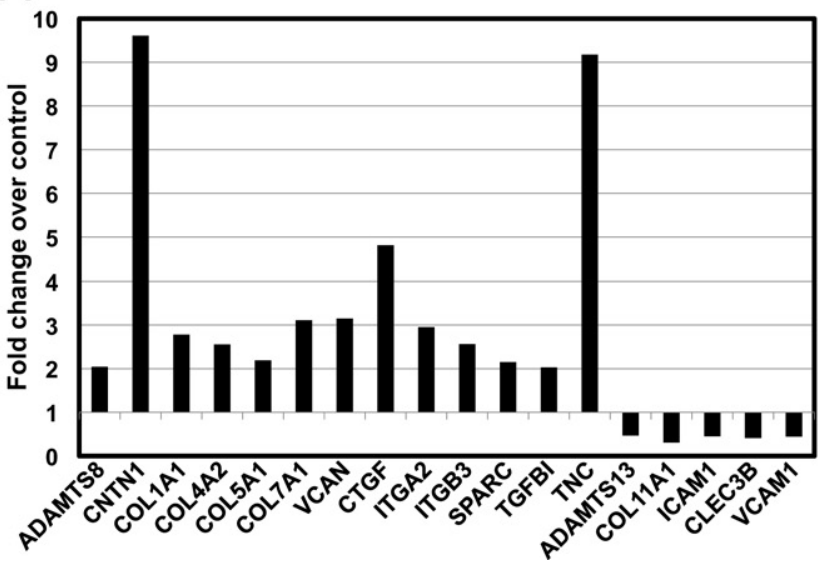

B

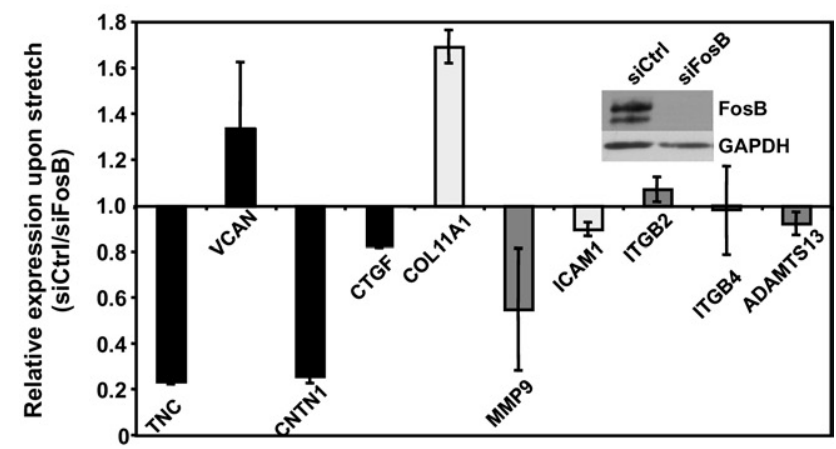

Figure 2. FosB activates ECM gene expression in pBSMCs. A: Induction or repression of genes in an ECM PCR array probed with cDNA from pBSMCs subjected to 24-hour cyclic stretch or control nonstretched cells. B: pBSMCs transfected with FosB siRNA were subjected to 24-hour stretch and evaluated for expression of a select subset of ECM genes, relative to control siRNA transfection. Genes in black indicate a reduction in expression (on FosB knockdown) of previously activated genes (in $\mathbf{A}$ ), whereas genes in gray indicate a change in expression of genes that were previously repressed by stretch. The graph is representative of three independent trials. Inset: An immunoblot illustrating the efficiency of knockdown.

were potential FosB targets, we knocked down expression of FosB in pBSMCs using RNA interference, exposed the cells to cyclic stretch-relaxation for 24 hours, and evaluated gene expression by real-time RT-PCR. As shown in Figure $2 \mathrm{~B}$, silencing of FosB led to marked decreases in expression of the stretch-induced genes TNC, CNTN1, VCAN, and CTGF, whereas it increased expression of the stretch-inhibited gene COL11A1. In contrast, knockdown of c-Fos, which is activated by stretch (Figure $1 \mathrm{C}$ ), did not attenuate the expression of these genes (data not shown), suggesting that FosB is the dominant regulator of the observed transcriptional changes in response to mechanical stimulation in pBSMCs.

\section{c-Jun and FosB Drive Expression of the Profibrotic Genes TNC and CTGF}

Among the cohort of genes identified as FosB targets in pBSMCs, we focused on TNC and CTGF because they encode well-known ECM proteins previously identified as mechanosensitive. ${ }^{6,23}$ Furthermore, they have been implicated in tissue responses to injury, such as adhesion, inflammation, fibrosis, cell proliferation, and migration in other hollow organs. ${ }^{24-29}$ Our novel observation that TNC and CTGF are transcriptional targets of FosB in SMCs prompted us to investigate whether overexpression of FosB could circumvent the requirement for the stretch stimulus in activating their expression. To this end, we generated reporter constructs, in which luciferase expression was under control of fragments of the human TNC (-996 bp) or CTGF (-759 bp) gene promoters and transiently expressed them in pBSMCs and HEK293 cells, along with plasmid expressing a tethered Jun$\sim$ FosB dimer or a control plasmid. We observed activation of TNC-luc (by 2-6-fold; Figure 3, A and B) and CTGF-luc (2-5-fold; Figure 3, D and E) in both cell types when co-expressed with the Jun $\sim$ FosB dimer, relative to control. To determine whether the effects of $c-J u n \sim F o s B$ reflected direct association of the transcriptional complex with chromatin, we performed ChIP analysis in stretched and nonstretched pBSMCs using p-c-Jun or control (IgG) antibodies. We evaluated $\mathrm{p}$-c-Jun binding to chromatin because it is the Jun family member that confers the DNA-binding activity of AP-1 and the p-c-Jun antibody used is comparatively well characterized for ChIP assays. Increased recruitment of p-c-Jun to AP-1 sites in the TNC (-876/-870) and CTGF (-650/-644) promoters was observed in cells exposed to stretch (Figure 3, C and F) compared with nonstretched cells, consistent with direct interaction between AP-1 complexes and the TNC and CTGF gene promoters.

Phosphorylation of the transactivation domain of c-Jun by JNK in response to a variety of stress stimuli is a crucial event in the activation of AP-1. ${ }^{30,31}$ To investigate the requirement for $\mathrm{C}$-Jun phosphorylation in activating transcription from the TNC and CTGF gene promoters, we treated quiescent pBSMCs for 1 hour with $10 \mu \mathrm{mol} / \mathrm{L}$ of JNK inhibitor (SP600125) or LY294002, the canonical phosphatidylinositol 3-kinase pathway inhibitor, followed by cyclic stretch for 24 hours, and evaluated TNC and CTGF mRNA levels. We previously implicated both the JNK and phosphatidylinositol 3-kinase/Akt pathways as mediators of mechanotransduction in $\mathrm{pBSMCs}^{4,5}$; however, the induction of CTGF and TNC mRNA on stretch was only attenuated in the presence of the JNK inhibitor, underlining the importance of signaling via the JNK/AP-1 cascade to regulate TNC and CTGF expression (Figure $3 \mathrm{G}$ ).

\section{Bladder Distension Up-Regulates AP-1 Subunits in Smooth Muscle}

Next, we evaluated expression of C-Jun and FosB in the intact bladder using two models of bladder stretch injury. In the first model, the bladder is distended and cultured ex vivo, such that the impact of distension can be studied in isolation from the neural or humoral inputs associated 


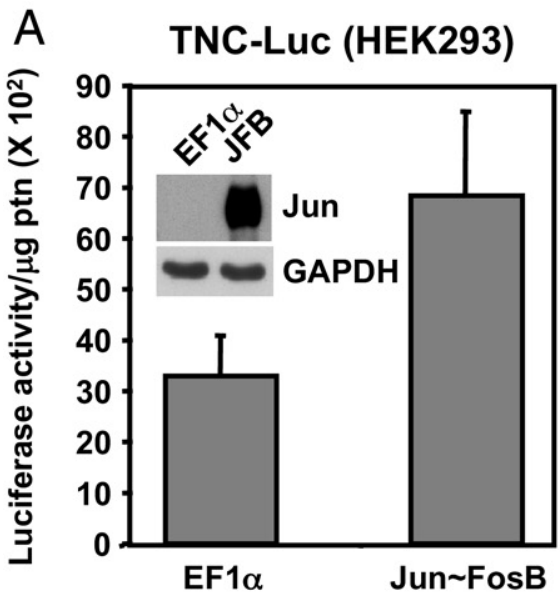

B
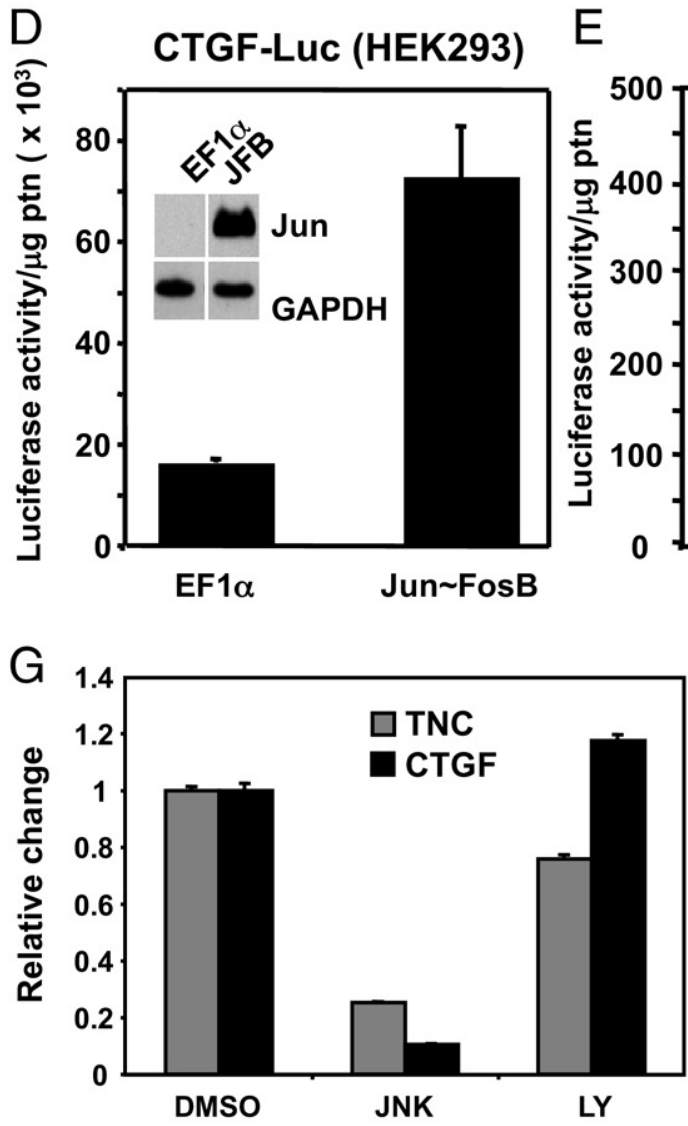
independent experiments.

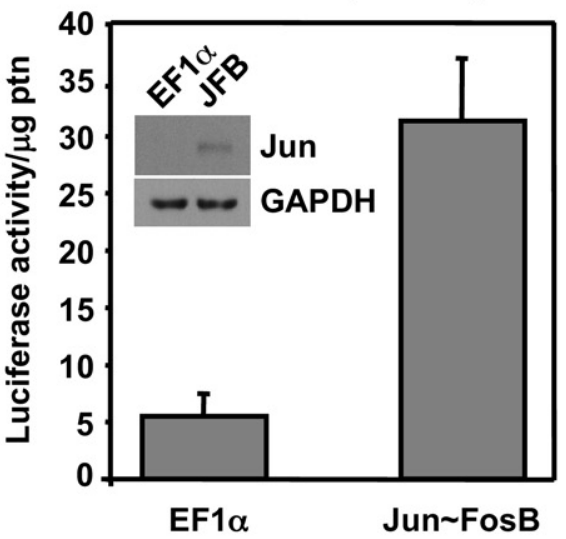

C TNC ChIP (BSMC)

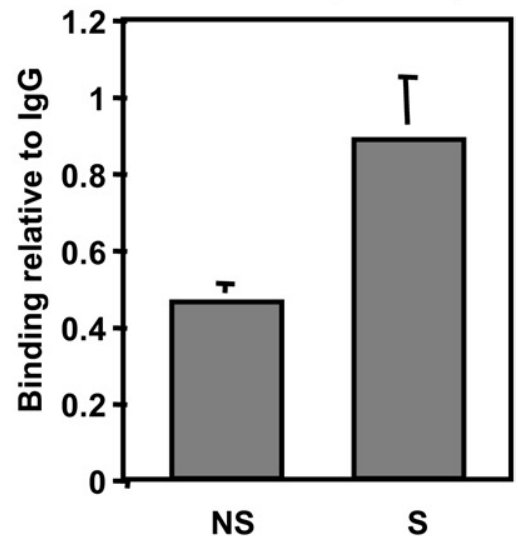

$\mathrm{F}$
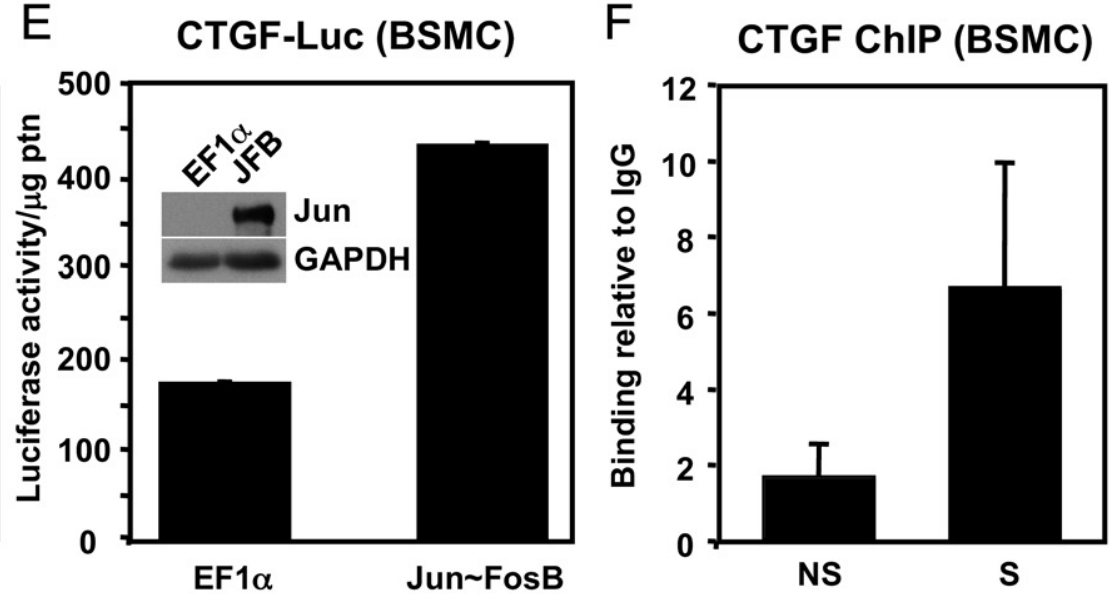

Figure 3. The TNC and CTGF gene promoters are bound and activated by AP-1. HEK293 cells (A) or pBSMCs (B) were cotransfected for 24 hours with a TNC-luc construct and an expression vector expressing a Jun $\sim$ FosB tethered AP-1 dimer (JFB) or control plasmid (EF1 $\alpha$ ). Insets: Expression of the dimer in the Jun $\sim$ FosB-transfected condition by immunoblotting for the c-Jun. C:ChIP assay showing increased phospho-c-Jun recruitment to the AP-1 site (-876) in the TNC promoter in pBSMCs subjected to stretch. $\mathbf{D}$ and E: Luciferase assays were performed as previously described, using the CTGF-luc construct. F: ChIP assay showing enhanced phospho-c-Jun recruitment to the $-650 \mathrm{AP}-1$ site in the endogenous CTGF promoter in pBSMCs, on stretch. NS, non-stretched; S, stretched. G: Real-time RT-PCR of TNC or CTGF mRNA levels in pBSMCs subjected to stretch for 24 hours after pretreatment for 1 hour with $10 \mu \mathrm{mol} / \mathrm{L}$ of JNK inhibitor (SP600125) or LY294002, the canonical phosphatidylinositol 3-kinase pathway inhibitor. Dimethyl sulfoxide (DMSO), control (cells treated with vehicle only). All data are representative of three or more

with bladder filling in the intact animal. ${ }^{16}$ Ex vivo distension of rat bladders for 2 hours led to enhanced expression and nuclear localization of both AP-1 subunits in bladder smooth muscle, compared with nondistended controls (Figure 4A). For each subunit, the number of positive nuclei was increased at least threefold, with distension relative to controls. In the second model, bladder distension is accomplished in vivo by complete urethral ligation for 24 hours, with distension arising from the animal's own urine production. Consistent with findings from ex vivo bladder injury, acute bladder outlet obstruction also led to increased nuclear localization of C-Jun and FosB (Figure 4B).

\section{TNC and CTGF Are Up-Regulated in Bladder} Smooth Muscle and Are FosB Targets

Next, we determined whether TNC and CTGF were regulated by bladder wall distension using the bladder stretch injury models previously described. After rat bladder distension ex vivo or acute outlet obstruction by urethral ligation in mice for 24 hours, bladders were embedded in optimal cutting temperature compound and subjected to laser-capture microdissection to isolate urothelial and smooth muscle components. As shown in Figure 5, robust expression of both TNC and CTGF was 

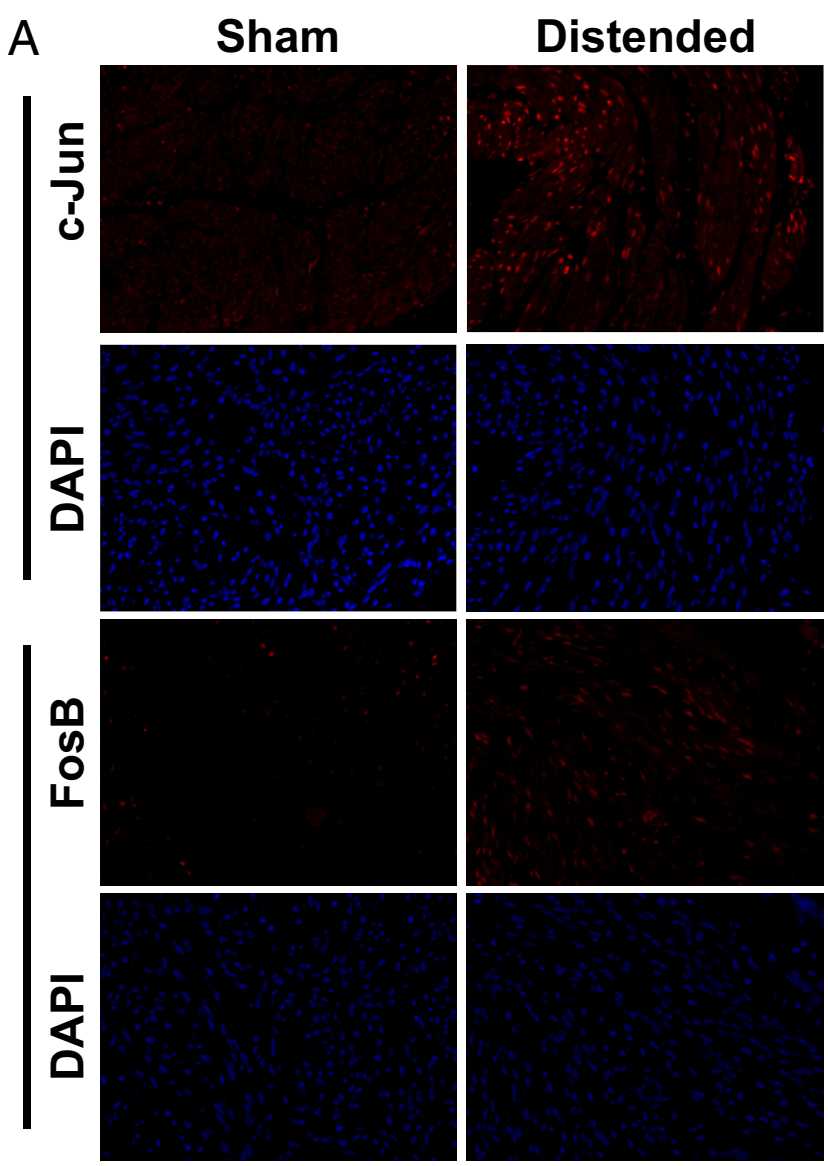

Sham

Distended

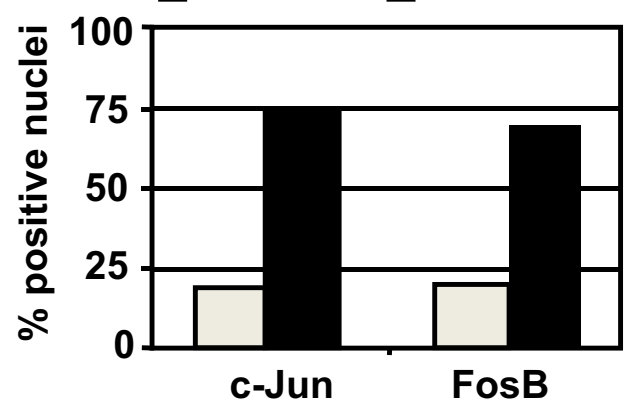

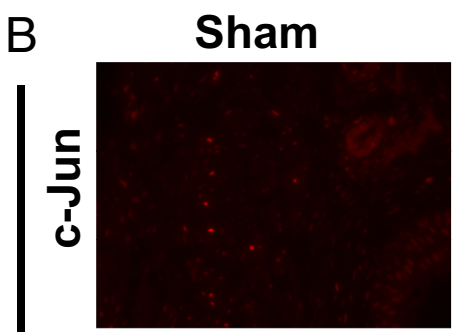

\section{Obstructed}
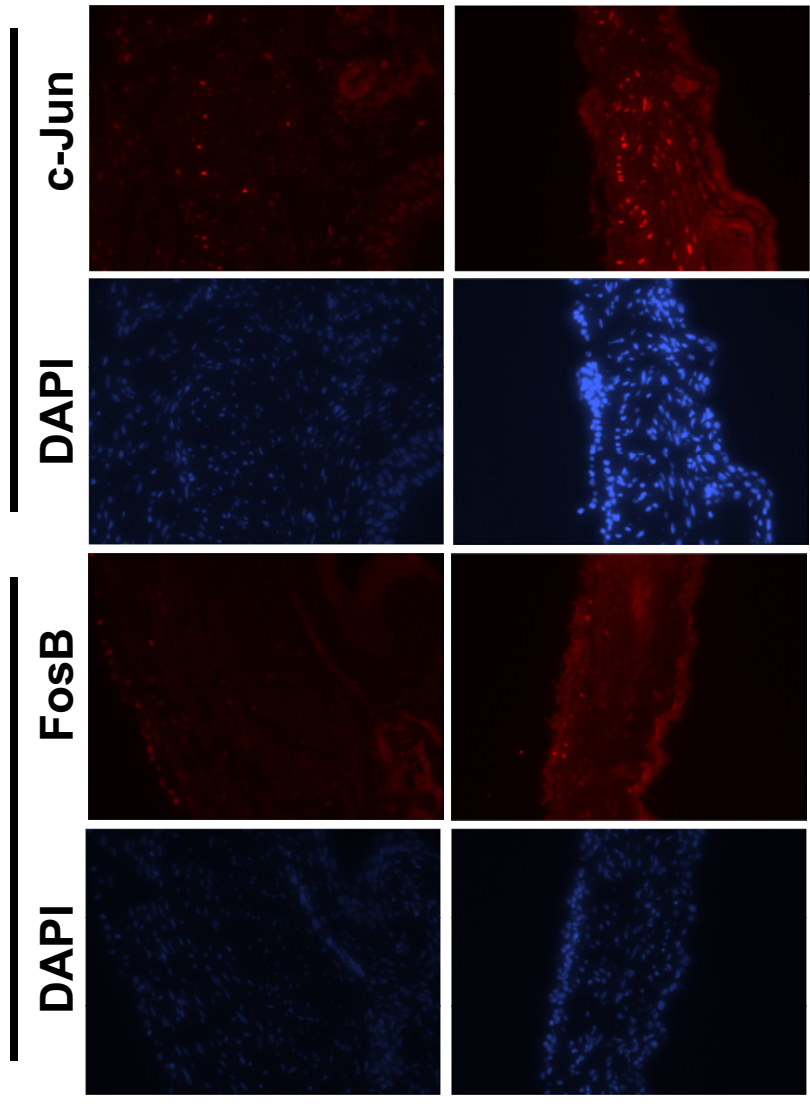

Sham

\section{Obstructed}

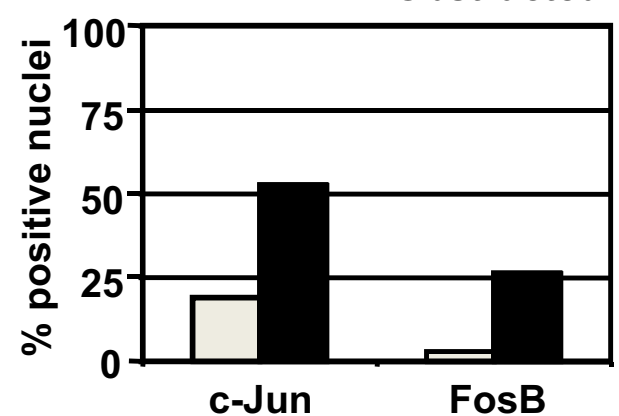

Figure 4. The nuclear localization of c-Jun and FosB proteins is increased in bladder smooth muscle on distension. A: Sections from rat bladders distended ex vivo for 8 hours were stained sequentially with anti-Jun or anti-FosB primary antibody and Cy3-conjugated species-specific secondary antibody. An increased nuclear fluorescent signal for both proteins was evident in the detrusor smooth muscle of distended specimens but not of nondistended sham operated on control bladders. Bottom panel: Quantitation of Jun and FosB nuclear staining in the detrusor compartment of sham and distended bladders. B: Sections from mouse bladders (control and subjected to short-term outlet obstruction for 24 hours) were stained with anti-Jun and anti-FosB antibodies, as previously indicated. Bottom panel: Quantitation of signal intensities in sham and obstructed bladder smooth muscle. Data are representative of at least two independent experiments.

observed in smooth muscle in response to distension either ex vivo (Figure 5, A and D) or in vivo (Figure 5, B and E), with minimal expression observed in smooth muscle isolated from sham (nondistended) specimens or urothelium (data not shown). We also evaluated CTGF and TNC protein expression in lysates prepared from ligated or sham-operated mouse bladders. Consistent with our mRNA results previously detailed, we observed a significant increase in CTGF and TNC protein levels in distended bladders relative to controls (Figure 5G). The induction of CTGF protein in response to distension was particularly striking, relative to TNC. This is in agreement with the fold increase in mRNA levels previously described for CTGF and TNC, highlighting a concordance between mRNA and protein levels for these genes.

To determine whether FosB was a mediator of TNC and CTGF expression in vivo, we subjected FosB-null mice to complete urethral ligation and assessed gene expression in response to bladder distension. Genetic ablation of FosB led to a marked reduction in distension- 
A

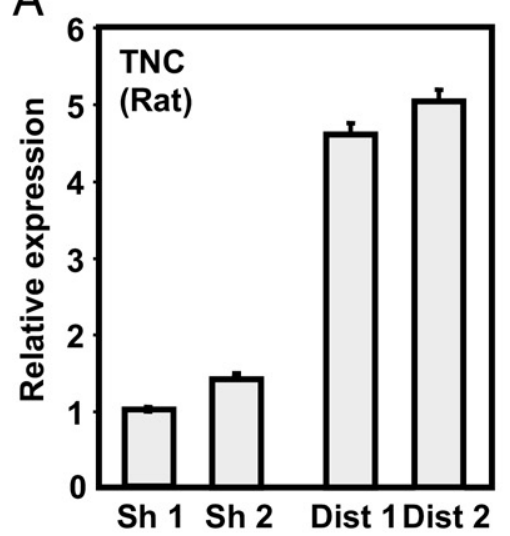

D

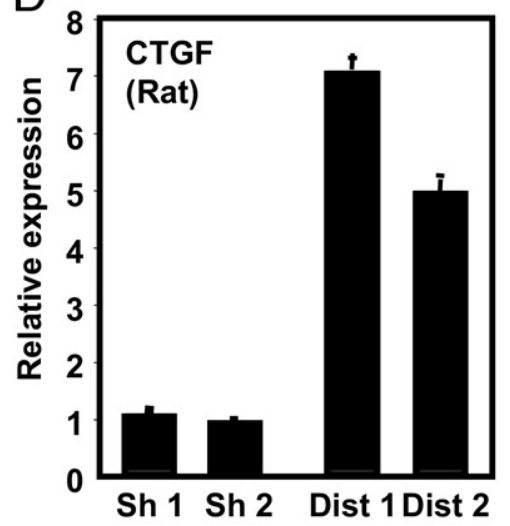

G

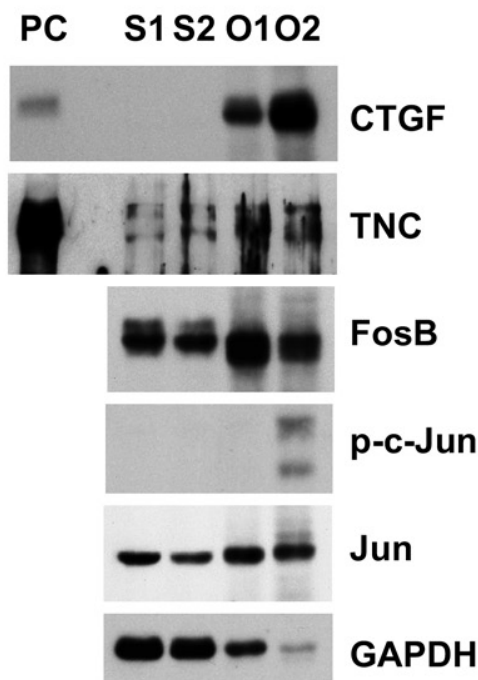

B

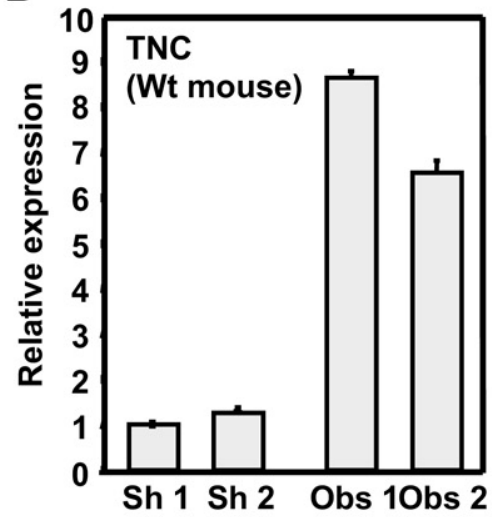

$E$

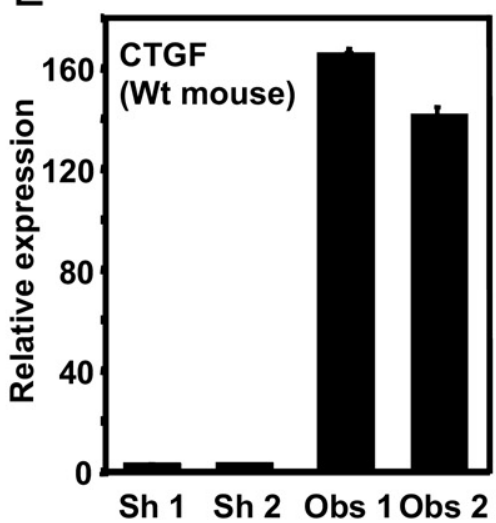

C

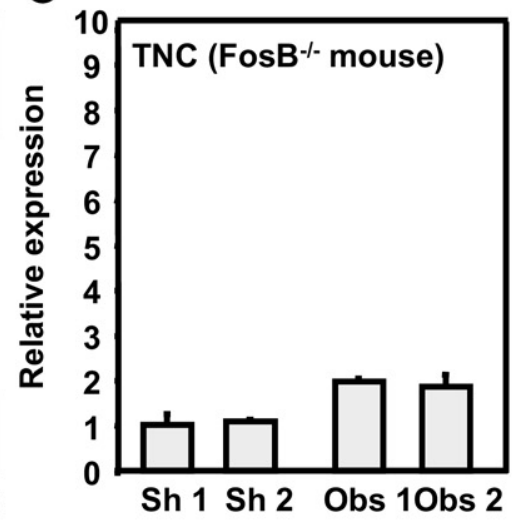

$\mathrm{F}$

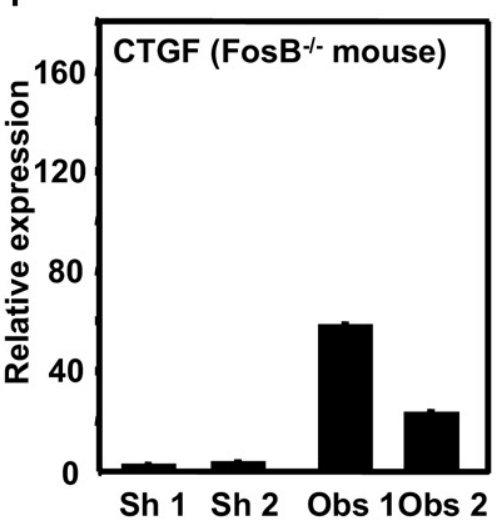

H $\quad$ aSh 1 aSh $2 \quad$ Obs 1 Oobs 2

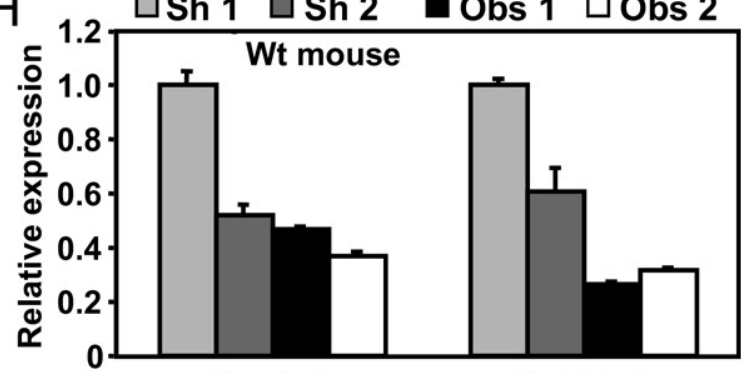

Col la1

Col Illa1

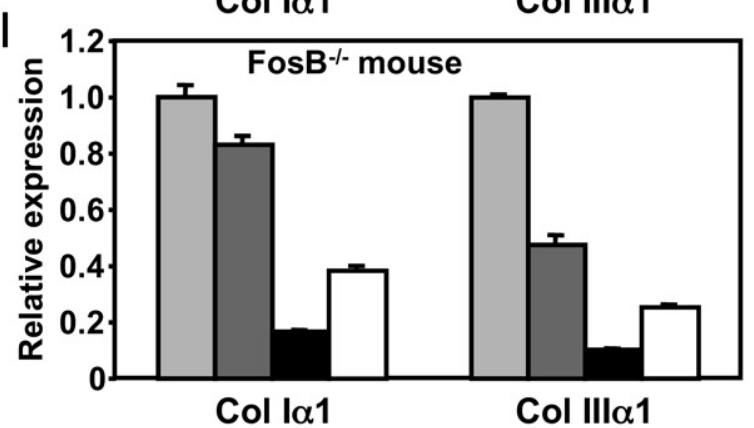

Figure 5. FosB drives stretch-induced TNC and CTGF gene expression in vivo. A: Real-time RT-PCR of TNC mRNA in rat bladder smooth muscle, following distension ex vivo for 8 hours to $40 \mathrm{~cm} \mathrm{H} \mathrm{H}_{2} \mathrm{O}$ pressure or nondistended [sham (Sh)] controls. B: TNC mRNA in the detrusor of mouse bladders secondary to urethral ligation for 24 hours or sham-operated animals. Wt, wild type. C: Obstructed bladders from FosB ${ }^{-1-}$ mice showed a marked decrease in TNC mRNA. The induction of CTGF mRNA in the smooth muscle compartment of rat bladders distended ex vivo (D), Wt mouse bladders 24 hours after obstruction (E), or FosB ${ }^{-1-}$ animals (F) is shown. In all cases, data from two animals are shown, normalized to Sh 1 TNC or CTGF mRNA levels. Dist, distended; Obs, obstructed. G: Whole bladder lysates from two sham (S) or outlet-obstructed (O) Wt mice were immunoblotted with the indicated antibodies. PC, positive control lysates (A10 and Hs68 cell extracts for CTGF and TNC proteins, respectively). mRNA levels for collagen (Col) I, III, and XII genes in smooth muscle microdissected from bladders of sham and obstructed Wt (H) or FosB ${ }^{-1-}$ (I) mice. Data from two sham-operated and two obstructed mice are shown. 
induced expression of TNC (Figure 5C) and CTGF (Figure 5F). Compared with wild-type mice (Figure 5, B and $\mathrm{E}$ ), induction of TNC and CTGF mRNA in bladder smooth muscle was suppressed $>75 \%$ in mice lacking FosB. Together, these observations identify FosB as an early and essential regulator of TNC and CTGF in bladder smooth muscle, both in vitro and in vivo. Notably, expression levels of collagens I and III, previously implicated in bladder wall remodeling, ${ }^{16,32}$ decreased in smooth muscle isolated from distended bladders relative to nondistended controls. However, collagen I and III levels did not differ significantly between wild-type and $\mathrm{FosB}^{-1-}$ mice (Figure 5, $\mathrm{H}$ and $\mathrm{I}$ ), indicating that FosB is unlikely to be essential for regulation of the collagen genes after acute bladder outlet obstruction.

\section{Discussion}

The AP-1 transcriptional complex is activated in response to a wide range of physiological and pathological stimuli, including mitogens and stress signals, and during normal growth and development. ${ }^{33}$ Although AP-1 is a mechanically sensitive transcriptional complex, ${ }^{34}$ the precise composition of AP-1 dimers induced by different mechanical stimuli has not been investigated. In this study, we identify FosB as a stretch-sensitive member of the AP-1 family and a novel regulator of ECM protein expression after mechanical stimulation of smooth muscle. The evidence supporting these conclusions is as follows: i) cyclic stretch-relaxation of primary bladder SMCs in monolayer culture led to increased DNA binding of AP-1 by EMSA; ii) ELISA-based analysis revealed increased DNA binding activity of FosB in response to stretch (but not the potent SMC mitogen platelet-derived growth factor); iii) distension of the intact rodent bladder led to increased nuclear localization of AP-1 subunits; iv) knockdown of FosB, but not of c-Fos, in pBSMCs led to attenuation of stretch-induced expression of genes encoding ECM proteins, including TNC and CTGF; and v) bladder distension ex vivo and in vivo led to increased expression of TNC and CTGF, and genetic ablation of FosB attenuated these effects. Together, these findings provide the first demonstration of a role for FosB in smooth muscle mechanotransduction and implicate FosB-containing AP-1 dimers as early triggers of fibroproliferative remodeling in smooth muscle-rich hollow organs (Figure 6).

Although FosB levels have increased in SMCs from other hollow organs exposed to mechanical stimuli, such as the uterus, ${ }^{15,35}$ evidence for a direct functional role for FosB in mechanotransduction is lacking. FosB was also mechanically responsive in osteoblasts. ${ }^{36,37}$ Exposure of osteoblasts to fluid shear stress by dynamic loading in mice led to a marked induction of FosB gene expression, through binding of cyclic AMP response element binding protein to a CRE/AP-1 motif located in the FosB promoter. ${ }^{36}$ In addition, FosB transcription was rapidly induced in human bone marrow-derived mesenchymal precursor cells during osteogenic differentiation induced by cyclic stretch. ${ }^{37}$ However, the relevance of increased

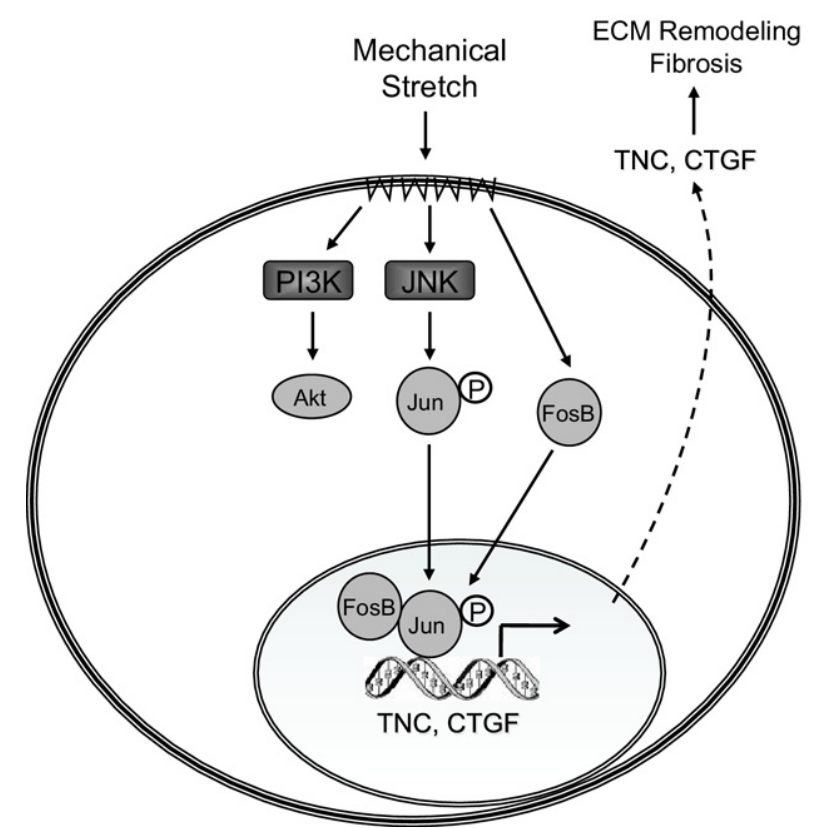

Figure 6. A model of FosB-mediated regulation of ECM genes by mechanical signaling in bladder smooth muscle. Exposure to acute bladder wall distension in vivo causes an increase in expression of AP- 1 family proteins. The expression of FosB and c-Jun, in particular, is enhanced, along with an increase in JNK-dependent phosphorylation (P) (and activation) of c-Jun. Jun $\sim$ FosB dimers formed subsequent to stretch bind to the promoters of ECM and matricellular genes, such as TNC and CTGF, increasing their mRNA and protein expression. TNC and CTGF are secreted into the ECM and trigger a pro-inflammatory and profibrotic response in the bladder wall. PI3K, phosphatidylinositol 3-kinase pathway inhibitor.

FosB transcription to either the transcriptional activity of FosB-containing AP-1 dimers or the regulation of cell behavior was not assessed in those studies. In this study, we used a combination of DNA-binding assays, RNA interference, mRNA expression analysis, ChIP, and reporter assays to demonstrate the requirement for FosB in stretch-stimulated expression of genes encoding ECM proteins in SMCs in vitro and in vivo and show that Jun$\sim$ FosB elicits its effects on expression through direct interaction with the gene promoters.

In addition to full-length FosB, at least two other forms of the protein have been described. $\triangle F$ FosB is homologous to FosB in the N-terminal 237 amino acids but lacks the $\mathrm{C}$-terminal region incorporating the transactivation domain. A second variant ( $\Delta 2 \Delta$ FosB) arises by alternative translation initiation from the $\Delta$ FosB transcript and lacks the N-terminal 78 amino acids that incorporate the Fos-homology domain. ${ }^{38,39}$ The expression of both $\Delta$ FosB and $\Delta 2 \Delta$ FosB was sensitive to mechanical stimulation of osteoblasts in vitro, ${ }^{36}$ and the protein products have altered bone formation in vivo. ${ }^{38,39}$ Interestingly, the effects of $\Delta$ FosB and $\Delta 2 \Delta$ FosB on bone formation were achieved independently of AP-1 binding to DNA, through activation of the BMP/Smad pathway, ${ }^{39}$ indicating that loss of the C-terminal transactivation domain alters the ability of FosB to interact with AP-1 motifs. In the current study, we observe activation of CTGF and TNC promoter reporter constructs after transient expression of a tethered Jun FosB dimer in both pBSMCs and HEK293 cells. Moreover, a point mutation of an AP-1 motif in the 
TNC promoter significantly attenuated Jun FosB-induced reporter activity (data not shown). The use of a cDNA encoding full-length FosB in these experiments rules out contributions from the splice variant $\Delta \mathrm{FosB}$ or its truncated form $\Delta 2 \Delta \mathrm{FosB}$ in TNC and CTGF promoter activation. Taken together, these observations suggest that FosB can mediate its transcriptional effects both directly, by interaction with AP-1 motifs, and indirectly, through other mechanisms.

In a study designed to investigate the contributions of distinct FosB isoforms to cell phenotype, Ohnishi and colleagues $^{40}$ generated mutant mouse embryonic stem cells expressing only full-length FosB or the two shorter isoforms alone and evaluated gene expression profiles and adhesion to different substrates. The expression of specific FosB isoforms altered levels of genes encoding constituents of the basement membrane and cell-matrix interactions, as measured by the extent of adhesion. An interesting conclusion of that study was that full-length FosB appeared to negatively regulate cell-matrix interactions and signaling via the transforming growth factor (TGF) $\beta$ pathway, whereas $\Delta$ FosB and $\Delta 2 \Delta \mathrm{FosB}$ promoted these effects, ${ }^{40}$ suggesting that the roles of FosB and its shorter isoforms are antagonistic. In our study, the RNAi-mediated knockdown in vitro and genetic ablation approaches in vivo targeted all three FosB isoforms. Therefore, the precise contribution of individual isoforms to the observed changes in ECM gene expression in pBSMCs and bladder tissue cannot be discriminated. However, the marked decrease in target gene expression observed after RNAi-mediated silencing in vitro and gene ablation in vivo, together with the induction in FosB-driven promoter luciferase expression, strongly underlines a critical role for the FosB family in driving ECM gene expression in response to mechanical stimulation.

Further evidence for cross talk between FosB and components of the TGF $\beta$ signaling network has emerged from analysis of several cell types. In particular, AP-1 subunits, including FosB $/ \Delta F o s B$, interacted with Smads; the association was essential for TGF $\beta$-mediated effects on target cells. ${ }^{41,42}$ Furthermore, in a three-dimensional in vitro model of adipocyte tissue transdifferentiation, overexpression of $\Delta$ FosB cooperated with the TGF $\beta$ family member BMP-2 to trigger remodeling of adiposelike microtissues to a more bonelike matrix, as evidenced by the reduction of adipocyte-specific markers, such as peroxisome proliferator-activated receptor- $\gamma$ and lipoprotein lipase, and an increase in both the expression of the osteoblast-specific markers osteocalcin and ostepontin and calcium deposition. ${ }^{43}$ Together, these findings strongly suggest that FosB functionally interacts with members of the TGF $\beta$ superfamily to regulate cell phenotype.

Such interactions between FosB/AP-1 and the TGF $\beta$ signaling axis are likely to be relevant to our observations of stretch-induced profibrotic gene expression in smooth muscle. Both TNC and CTGF expression levels are potently stimulated in other tissues by TGF $\beta,{ }^{44-47}$ a key mediator of tissue fibrosis. ${ }^{48}$ Moreover, we found that the TGF $\beta$-induced gene TGFB/ was up-regulated by stretch in pBSMCs (Figure 2), suggesting involvement of TGF $\beta$ - mediated signals in SMC mechanotransduction. CTGF is an early and crucial driver of profibrotic responses in vivo $^{49}$ and regulates its own expression in an autocrine fashion. ${ }^{50-53}$ Notably, CTGF autoregulation is regulated, at least in part, through synergistic interactions with TGF $\beta /$ Smad-dependent signaling cascades. ${ }^{53}$ JNK-regulated AP-1 signaling has also been implicated in the regulation of CTGF-induced CTGF expression, ${ }^{54}$ in a form of glaucoma in which cells are exposed to increased pressure, in agreement with our observations demonstrating JNK/AP-1-mediated regulation of CTGF in SMCs. Interestingly, AP-1 drives stretch-induced TGF $\beta$ expression in airway SMCs, ${ }^{55}$ highlighting another mechanism by which induction of this family of proteins can trigger and maintain cellular responses in mechanically sensitive tissues.

Among the molecules that contribute to fibrosis of hollow organs, collagens I and III have been the most intensively studied, with alterations in the collagen I:collagen III ratio evident in tissue from patients with bladder fibrosis. ${ }^{32}$ In two models of bladder wall injury, we observed decreased levels of both collagen I and III mRNAs in distended tissues compared with controls (Figure 5). More important, a similar expression pattern was obtained in tissues from FosB-null mice, suggesting that, under the conditions used herein, the collagen I and III genes are not stretch-sensitive transcriptional targets of FosB. Published studies have reported variable expression of collagens in experimental models of bladder cell stretch or pressure, with some studies ${ }^{16}$ describing findings consistent with a decreased collagen I/collagen III ratio, but others ${ }^{56,57}$ reporting no change in steady-state levels of collagen I and III mRNA in response to stress stimuli. The reasons for such differences have not been described but may relate to variations in experimental formats, such as species, model system, and/or duration of insult.

Studies have demonstrated that mechanical stimuli activate multiple transcription factors in smooth muscle, including Ets factors, AP-1, and NF- $\kappa \mathrm{B}, 3,4,7,8$ all of which regulate TNC and CTGF expression in different cell types. ${ }^{58-66}$ In many cases, however, AP-1 dimer composition and the biological consequence of these interactions have not been addressed. Our current findings provide the first evidence for a direct role of FosB-containing AP-1 dimers in regulation of TNC and CTGF and demonstrate an essential role for this subunit in driving their expression. More important, although the DNA-binding activity of both subunits was enhanced by stretch in pBSMCs, FosB and c-Fos appear to have nonoverlapping roles in SMC mechanotransduction. In particular, the expression of c-Fos did not compensate for the loss of FosB function in ECM gene regulation. Moreover, RNAi-mediated knockdown of c-Fos failed to attenuate stretch-induced expression of TNC, CTGF, and other genes encoding components of the ECM, suggesting selectivity in target gene regulation and highlighting the relevance of AP-1 dimer composition to transcriptional activity. These findings are in agreement with a previous report $^{67}$ that provided an elegant demonstration of the extent to which dimer composition regulates AP-1 activity. In that study, Bakiri and colleagues ${ }^{67}$ evaluated the relative potency of so-called tethered AP-1 dimers, com- 
posed of c-Jun covalently linked to Fra1, Fra2, or c-Fos via a flexible linker. Notably, distinct qualitative and quantitative differences in the ability of specific dimers to activate known AP-1-dependent promoter-reporter constructs and elicit biological effects in target cells were observed. In particular, the identity of the Fos family partner for c-Jun was a key determinant of cell behavior, in agreement with our demonstration that FosB, but not c-Fos, was essential for ECM gene expression in smooth muscle mechanotransduction.

In summary, our study demonstrates, for the first time to our knowledge, a role for AP-1 in regulating the expression of TNC and CTGF expression in smooth muscle subjected to mechanical stretch. More important, these findings identify FosB as a novel and critical driver of stretch-induced expression of ECM gene expression during stress-induced fibroproliferative remodeling. These findings suggest that the early and robust induction of matricellular gene expression after bladder wall distension initiates a potent cascade of profibrotic signaling. Moreover, our demonstration that genetic ablation of FosB leads to reduced expression of both TNC and CTGF in vitro and in vivo implies that FosB represents a potential node for therapeutic intervention to mitigate the deleterious effects of pathological tissue remodeling.

\section{Acknowledgments}

We thank Drs. Michael Freeman, Joshua Mauney, and Carlos Estrada and members of the Urological Diseases Research Center for helpful discussions.

\section{References}

1. Mammoto T, Ingber DE: Mechanical control of tissue and organ development. Development 2010, 137:1407-1420

2. Hinz B: The myofibroblast: paradigm for a mechanically active cell. J Biomech 2010, 43:146-155

3. Park JM, Adam RM, Peters CA, Guthrie PD, Sun Z, Klagsbrun M, Freeman MR: AP-1 mediates stretch-induced expression of HB-EGF in bladder smooth muscle cells. Am J Physiol 1999, 277:C294-C301

4. Nguyen HT, Adam RM, Bride SH, Park JM, Peters CA, Freeman MR: Cyclic stretch activates p38 SAPK2-, ErbB2-, and AT1-dependent signaling in bladder smooth muscle cells. Am J Physiol Cell Physiol 2000, 279:C1155-C1167

5. Adam RM, Roth JA, Cheng HL, Rice DC, Khoury J, Bauer SB, Peters CA, Freeman MR: Signaling through PI3K/Akt mediates stretch and PDGF-BB-dependent DNA synthesis in bladder smooth muscle cells. J Urol 2003, 169:2388-2393

6. Adam RM, Eaton SH, Estrada C, Nimgaonkar A, Shih SC, Smith LE, Kohane IS, Bagli D, Freeman MR: Mechanical stretch is a highly selective regulator of gene expression in human bladder smooth muscle cells. Physiol Genomics 2004, 20:36-44

7. Persson K, Dean-Mckinney T, Steers WD, Tuttle JB: Activation of the transcription factors nuclear factor-kappaB and activator protein-1 in bladder smooth muscle exposed to outlet obstruction and mechanical stretching. J Urol 2001, 165:633-639

8. Sooranna SR, Lee Y, Kim LU, Mohan AR, Bennett PR, Johnson MR: Mechanical stretch activates type 2 cyclooxygenase via activator protein-1 transcription factor in human myometrial cells. Mol Hum Reprod 2004, 10:109-113

9. Jochum W, Passegue E, Wagner EF: AP-1 in mouse development and tumorigenesis. Oncogene 2001, 20:2401-2412

10. Wang JH, Thampatty BP: An introductory review of cell mechanobiology. Biomech Model Mechanobiol 2006, 5:1-16
11. Renault MA, Jalvy S, Belloc I, Pasquet S, Sena S, Olive M, Desgranges C, Gadeau AP: AP-1 is involved in UTP-induced osteopontin expression in arterial smooth muscle cells. Circ Res 2003, 93:674-681

12. Alfonso-Jaume MA, Bergman MR, Mahimkar R, Cheng S, Jin ZQ, Karliner JS, Lovett DH: Cardiac ischemia-reperfusion injury induces matrix metalloproteinase-2 expression through the AP-1 components FosB and JunB. Am J Physiol Heart Circ Physiol 2006, 291:H1838H1846

13. Bertrand-Philippe M, Ruddell RG, Arthur MJ, Thomas J, Mungalsingh $\mathrm{N}$, Mann DA: Regulation of tissue inhibitor of metalloproteinase 1 gene transcription by RUNX1 and RUNX2. J Biol Chem 2004, 279: $24530-24539$

14. Shi ZD, Ji XY, Berardi DE, Qazi H, Tarbell JM: Interstitial flow induces MMP-1 expression and vascular SMC migration in collagen I gels via an ERK 1/2-dependent and c-Jun-mediated mechanism. Am J Physiol Heart Circ Physiol 2010, 298:H127-H135

15. Mitchell JA, Shynlova O, Langille BL, Lye SJ: Mechanical stretch and progesterone differentially regulate activator protein-1 transcription factors in primary rat myometrial smooth muscle cells. Am J Physio Endocrinol Metab 2004, 287:E439-E445

16. Capolicchio G, Aitken KJ, Gu JX, Reddy P, Bagli DJ: Extracellular matrix gene responses in a novel ex vivo model of bladder stretch injury. J Urol 2001, 165:2235-2240

17. Upadhyay J, Aitken KJ, Damdar C, Bolduc S, Bagli DJ: Integrins expressed with bladder extracellular matrix after stretch injury in vivo mediate bladder smooth muscle cell growth in vitro. J Urol 2003, 169:750-755

18. Ramachandran A, Ranpura SA, Gong EM, Mulone M, Cannon GM Jr, Adam RM: An Akt- and Fra-1-dependent pathway mediates plateletderived growth factor-induced expression of thrombomodulin, a novel regulator of smooth muscle cell migration. Am J Pathol 2010, 177:119-131

19. Estrada CR, Adam RM, Eaton SH, Bagli DJ, Freeman MR: Inhibition of EGFR signaling abrogates smooth muscle proliferation resulting from sustained distension of the urinary bladder. Lab Invest 2006, 86: 1293-1302

20. Borer JG, Park JM, Atala A, Nguyen HT, Adam RM, Retik AB, Freeman MR: Heparin-binding EGF-like growth factor expression increases selectively in bladder smooth muscle in response to lower urinary tract obstruction. Lab Invest 1999, 79:1335-1345

21. Brown JR, Ye H, Bronson RT, Dikkes P, Greenberg ME: A defect in nurturing in mice lacking the immediate early gene fosB. Cell 1996, 86:297-309

22. Rothman A, Wolner B, Button D, Taylor P: Immediate-early gene expression in response to hypertrophic and proliferative stimuli in pulmonary arterial smooth muscle cells. J Biol Chem 1994, 269: 6399-6404

23. Yang R, Amir J, Liu H, Chaqour B: Mechanical strain activates a program of genes functionally involved in paracrine signaling of angiogenesis. Physiol Genomics 2008, 36:1-14

24. Dobaczewski M, Gonzalez-Quesada C, Frangogiannis NG: The extracellular matrix as a modulator of the inflammatory and reparative response following myocardial infarction. J Mol Cell Cardiol 2010, 48:504-511

25. Chiquet M, Tunc-Civelek V, Sarasa-Renedo A: Gene regulation by mechanotransduction in fibroblasts. Appl Physiol Nutr Metab 2007, 32:967-973

26. Trebaul A, Chan EK, Midwood KS: Regulation of fibroblast migration by tenascin-C. Biochem Soc Trans 2007, 35:695-697

27. Leask A: Potential therapeutic targets for cardiac fibrosis: TGFbeta, angiotensin, endothelin, CCN2, and PDGF, partners in fibroblast activation. Circ Res 2010, 106:1675-1680

28. Leask A, Parapuram SK, Shi-Wen X, Abraham DJ: Connective tissue growth factor (CTGF, CCN2) gene regulation: a potent clinical biomarker of fibroproliferative disease? J Cell Commun Signal 2009, 3:89-94

29. Phanish MK, Winn SK, Dockrell ME: Connective tissue growth factor(CTGF. CCN2): a marker, mediator and therapeutic target for renal fibrosis. Nephron Exp Nephrol 2010, 114:e83-e92

30. Kyriakis JM, Banerjee P, Nikolakaki E, Dai T, Rubie EA, Ahmad MF, Avruch J, Woodgett JR: The stress-activated protein kinase subfamily of C-Jun kinases. Nature 1994, 369:156-160 
31. Aguilera C, Nakagawa K, Sancho R, Chakraborty A, Hendrich B, Behrens $\mathrm{A}$ : C-Jun N-terminal phosphorylation antagonises recruitment of the Mbd3/NuRD repressor complex. Nature 2011, 469: 231-235

32. Deveaud CM, Macarak EJ, Kucich U, Ewalt DH, Abrams WR, Howard PS: Molecular analysis of collagens in bladder fibrosis. J Urol 1998 160:1518-1527

33. Shaulian E, Karin M: AP-1 as a regulator of cell life and death. Nat Cell Biol 2002, 4:E131-E136

34. Li C, Xu Q: Mechanical stress-initiated signal transductions in vascular smooth muscle cells. Cell Signal 2000, 12:435-445

35. Mitchell JA, Lye SJ: Differential expression of activator protein-1 transcription factors in pregnant rat myometrium. Biol Reprod 2002 67:240-246

36. Inoue D, Kido S, Matsumoto T: Transcriptional induction of FosB/ DeltaFosB gene by mechanical stress in osteoblasts. J Biol Chem 2004, 279:49795-49803

37. Haasper C, Jagodzinski M, Drescher M, Meller R, Wehmeier M, Krettek C, Hesse E: Cyclic strain induces FosB and initiates osteogenic differentiation of mesenchymal cells. Exp Toxicol Pathol 2008, 59:355-363

38. Sabatakos G, Sims NA, Chen J, Aoki K, Kelz MB, Amling M, Bouali Y, Mukhopadhyay K, Ford K, Nestler EJ, Baron R: Overexpression of DeltaFosB transcription factor(s) increases bone formation and inhibits adipogenesis. Nat Med 2000, 6:985-990

39. Sabatakos G, Rowe GC, Kveiborg M, Wu M, Neff L, Chiusaroli R, Philbrick WM, Baron R: Doubly truncated FosB isoform (Delta2DeltaFosB) induces osteosclerosis in transgenic mice and modulates expression and phosphorylation of Smads in osteoblasts independent of intrinsic AP-1 activity. J Bone Miner Res 2008, 23 : 584-595

40. Ohnishi YN, Sakumi K, Yamazaki K, Ohnishi YH, Miura T, Tominaga $Y$, Nakabeppu Y: Antagonistic regulation of cell-matrix adhesion by FosB and DeltaFosB/Delta2DeltaFosB encoded by alternatively spliced forms of fosB transcripts. Mol Biol Cell 2008, 19:47174729

41. Schneiders D, Heger J, Best P, Michael Piper H, Taimor G: SMAD proteins are involved in apoptosis induction in ventricular cardiomyocytes. Cardiovasc Res 2005, 67:87-96

42. Lai CF, Cheng SL: Signal transductions induced by bone morphogenetic protein-2 and transforming growth factor-beta in normal human osteoblastic cells. J Biol Chem 2002, 277:15514-15522

43. Diaz Sanchez-Bustamante C, Kelm JM, Egermann M, Djonov V, Fussenegger M: Ectopic expression of delta FBJ murine osteosarcoma viral oncogene homolog B mediates transdifferentiation of adipose-like spheroids into osteo-like microtissues. Tissue Eng Part A 2008, 14:1377-1394

44. Pearson CA, Pearson D, Shibahara S, Hofsteenge J, Chiquet-Ehrismann R: Tenascin: cDNA cloning and induction by TGF-beta. EMBO J 1988, 7:2977-2982

45. Igarashi A, Okochi H, Bradham DM, Grotendorst GR: Regulation of connective tissue growth factor gene expression in human skin fibroblasts and during wound repair. Mol Biol Cell 1993, 4:637645

46. Grotendorst GR, Okochi H, Hayashi N: A novel transforming growth factor beta response element controls the expression of the connective tissue growth factor gene. Cell Growth Differ 1996, 7:469-480

47. Leask A: Signaling in fibrosis: targeting the TGF beta, endothelin-1 and CCN2 axis in scleroderma. Front Biosci (Elite Ed) 2009, 1:115-122

48. Prud'homme GJ: Pathobiology of transforming growth factor beta in cancer, fibrosis and immunologic disease, and therapeutic considerations. Lab Invest 2007, 87:1077-1091

49. Gressner OA, Gressner AM: Connective tissue growth factor: a fibrogenic master switch in fibrotic liver diseases. Liver Int 2008, 28 : 1065-1079
50. Johnson PR, Burgess JK, Ge Q, Poniris M, Boustany S, Twigg SM, Black JL: Connective tissue growth factor induces extracellular matrix in asthmatic airway smooth muscle. Am J Respir Crit Care Med 2006, 173:32-41

51. Aikawa T, Gunn J, Spong SM, Klaus SJ, Korc M: Connective tissue growth factor-specific antibody attenuates tumor growth, metastasis, and angiogenesis in an orthotopic mouse model of pancreatic cancer. Mol Cancer Ther 2006, 5:1108-1116

52. Perng DW, Wu YC, Tsai CC, Su KC, Liu LY, Hsu WH, Lee YC: Bile acids induce CCN2 production through p38 MAP kinase activation in human bronchial epithelial cells: a factor contributing to airway fibrosis. Respirology 2008, 13:983-989

53. Trojanowska M: Noncanonical transforming growth factor beta signaling in scleroderma fibrosis. Curr Opin Rheumatol 2009, 21 : 623-629

54. Browne JG, Ho SL, Kane R, Oliver N, Clark AF, O'Brien CJ, Crean JK: Connective tissue growth factor is increased in pseudoexfoliation glaucoma. Invest Ophthalmol Vis Sci 2011, 52:3660-3666

55. Mohamed JS, Boriek AM: Stretch augments TGF-beta1 expression through RhoA/ROCK1/2, PTK, and PI3K in airway smooth muscle cells. Am J Physiol Lung Cell Mol Physiol 2010, 299:L413-L424

56. Peters CA, Freeman MR, Fernandez CA, Shepard J, Wiederschain DG, Moses MA: Dysregulated proteolytic balance as the basis of excess extracellular matrix in fibrotic disease. Am J Physiol 1997, 272:R1960-R1965

57. Backhaus BO, Kaefer M, Haberstroh KM, Hile K, Nagatomi J, Rink RC, Cain MP, Casale A, Bizios R: Alterations in the molecular determinants of bladder compliance at hydrostatic pressures less than 40 cm. $\mathrm{H}_{2} \mathrm{O}$. J Urol 2002, 168:2600-2604

58. Chiquet-Ehrismann R, Tannheimer M, Koch M, Brunner A, Spring J, Martin D, Baumgartner S, Chiquet M: Tenascin-C expression by fibroblasts is elevated in stressed collagen gels. J Cell Biol 1994, 127:2093-2101

59. Mettouchi A, Cabon F, Montreau N, Dejong V, Vernier P, Gherzi R, Mercier G, Binetruy B: The C-Jun-induced transformation process involves complex regulation of tenascin-C expression. Mol Cell Biol 1997, 17:3202-3209

60. Goh FG, Piccinini AM, Krausgruber T, Udalova IA, Midwood KS: Transcriptional regulation of the endogenous danger signal tenascin-C: a novel autocrine loop in inflammation. J Immunol 2010, 184:2655-2662

61. Shirasaki F, Makhluf HA, LeRoy C, Watson DK, Trojanowska M: Ets transcription factors cooperate with Sp1 to activate the human tenascin-C promoter. Oncogene 1999, 18:7755-7764

62. Yamamoto K, Dang QN, Kennedy SP, Osathanondh R, Kelly RA, Lee $\mathrm{RT}$ : Induction of tenascin-C in cardiac myocytes by mechanical deformation: role of reactive oxygen species. J Biol Chem 1999, 274:21840-21846

63. Nakerakanti SS, Kapanadze B, Yamasaki M, Markiewicz M, Trojanowska M: Fli1 and Ets1 have distinct roles in connective tissue growth factor/CCN2 gene regulation and induction of the profibrotic gene program. J Biol Chem 2006, 281:25259-25269

64. Yu CC, Hsu MJ, Kuo ML, Chen RF, Chen MC, Bai KJ, Yu MC, Chen $\mathrm{BC}$, Lin $\mathrm{CH}$ : Thrombin-induced connective tissue growth factor expression in human lung fibroblasts requires the ASK1/JNK/AP-1 pathway. J Immunol 2009, 182:7916-7927

65. Recchia AG, Filice E, Pellegrino D, Dobrina A, Cerra MC, Maggiolini $\mathrm{M}$ : Endothelin-1 induces connective tissue growth factor expression in cardiomyocytes. J Mol Cell Cardiol 2009, 46:352-359

66. Chaqour B, Yang R, Sha Q: Mechanical stretch modulates the promoter activity of the profibrotic factor CCN2 through increased actin polymerization and NF-kappaB activation. J Biol Chem 2006, 281: 20608-20622

67. Bakiri L, Matsuo K, Wisniewska M, Wagner EF, Yaniv M: Promoter specificity and biological activity of tethered AP-1 dimers. Mol Cell Biol 2002, 22:4952-4964 